\title{
Biological control of insect pests in Puerto Rico'
}

\author{
Fernando Gallardo-Covas ${ }^{2}$
}

J. Agric. Univ. P.R. 101:153-163 (2017)

\begin{abstract}
The first documented observation on biological control of insects in Puerto Rico was made by botanist Andres Pedro Ledrú who arrived on the island in 1797 with a commission of French scientists. Much later (18801887), Johannes Gundlach classified braconid wasps of the genus Conura. In 1895, Fernando López-Tuero published a treatise on sugarcane and the beneficial effects of Apanteles sp. and Euplectrus sp., two natural enemies of the sugarcane borer Diatraea saccharalis F. Since then more than 75 natural enemies were introduced, some very effective like the toad Bufo marinus $L$. in controlling white grubs in sugarcane, and others partially effective like the coffee leafminer parasitoid, Mirax insularis Muesebeck. Also, natural enemies were exported from Puerto Rico to other countries as far away as Mauritania. However, with the advent of chlorinated insecticides derived from DDT, in the early 1950 s, the work on biocontrol declined dramatically, and not until the mid-1980s was biological control again considered a remedy to the problem of pests. In Puerto Rico, research was focused more on recognizing the endemic fauna of natural enemies and the introduction of parasitoids/ predators. This paper presents a historical review and discussion of trends and approaches to the biological control of pests from its beginnings to the present.
\end{abstract}

Key words: entomology, Puerto Rico, biological control, parasitoids, predators

\section{RESUMEN}

Control biológico de los insectos plaga en Puerto Rico: Revisión bibliográfica

La primera observación documentada sobre control biológico de insectos en Puerto Rico fue hecha por el botánico Andrés Pedro Ledrú, quien llegó con una comisión de científicos franceses en el 1797. Más tarde (1880 al 1887) el alemán Johannes Gundlach clasifica avispas bracónidas del género Conura. En el año 1895 el español Fernando López-Tuero publica un tratado sobre la caña de azúcar y los efectos beneficiosos de Apanteles sp. y Euplectrus sp., dos parasitoides del taladrador de la caña, Diatraea saccharalis $F$. Desde entonces más de 75 enemigos naturales fueron introducidos, algunos muy efectivos como el sapo Bufo marinus $L$. para

${ }^{1}$ Presented at Entomology Symposium: Legacy of the International Institute of Tropical Forestry (IITF) 75th Anniversary, March 17-18, 2017, San Juan, P.R.

${ }^{2}$ Professor of Entomology, Department of Agroenvironmental Sciences, College of Agricultural Sciences, Mayagüez Campus-University of Puerto Rico. 


\begin{abstract}
controlar los gusanos del suelo en la caña y otros parcialmente efectivos como el bracónido Mirax insularís Muesebeck, parasitoide del minador del café. También fueron exportados enemigos naturales de Puerto Rico hacia otros países tan lejanos como Mauritania. Sin embargo, con la aparición de los insecticidas clorados derivados del DDT, a principios de la década del 50, los trabajos de biocontrol disminuyeron dramáticamente y no fue hasta mediados de los años 80 que comenzó nuevamente a considerarse la lucha biológica como remedio al problema de las plagas. En Puerto Rico, la investigación ha sido enfocada principalmente en trabajos de taxonomía para reconocer la fauna endémica de enemigos naturales y la introducción de parasitoides/depredadores. Este trabajo presenta una revisión histórica y discusión de las tendencias o enfoques de la lucha biológica de plagas desde sus comienzos hasta la actualidad.
\end{abstract}

Palabras clave: entomología, Puerto Rico, control biológico, parasitoides, depredadores

\title{
INTRODUCTION
}

The use of natural enemies (predators, parasites and pathogens) to suppress insect-pest populations and phytophages is the branch of economic entomology known as biological control. This concept does not include other alternatives or methods of biological control such as resistant transgenic plants or genetic control. The objective of this paper is to provide an updated and comprehensive view of the biological control of insect pests in Puerto Rico. This goal is achieved through a comprehensive literature review from its inception in 1797 until 2015. During those 218 years, 407 research papers have been published, representing $16 \%$ of all entomological literature on Puerto Rico (unpublished data).

\section{HISTORICAL DEVELOPMENT OF BIOLOGICAL CONTROL IN PUERTO RICO UNTIL 2015}

\section{The foundations - 19th Century}

The first documented observation on biological control of insects in Puerto Rico was made by botanist Andre Pierre Ledrú who came to Puerto Rico in 1797 with a commission of French scientists (Ledrú, 1810). In his chronicle, Ledrú describes 46 common insects from Puerto Rico including wasps: "All of them attack animals, are voracious, and make war against other insects." Almost 100 years later, in 1880, the German naturalist Johannes Gundlach began publishing the "Fauna Puerto-Riqueña" in the "Anales de la Sociedad Española de Historia Natural, Madrid' (Gundlach, 1887). The collected specimens were identified in Berlin and Switzerland and included several parasitic wasps of the Chalcididae family classified as genus Smicra (Conura). Gundlach identified four species: S. punctata, S. ignea, S. emarginata and 
S. flavopicta, noting: "The larvae of all species of this family are raised within the body of caterpillars and larvae, or pupae and nymphs, thus being useful to Agriculture...”. He also describes the habits of a parasitic wasp parasitoid in egg cases of cockroaches Evania laevigata (appendigaster E. Guerin-Ménéville).

Later, in 1895, the Spanish agronomist Fernando López-Tuero, director of the Agronomic Station of Río Piedras, published a treatise on sugarcane (López-Tuero, 1895). He mentioned the beneficial effects of Apanteles sp. and Euplectrus sp., two natural enemies of the sugarcane borer, Diatraea saccharalis (Fabricáis). The fourth chapter describes in detail how to use the parasitoids to control the sugarcane borer, and recognizes the beneficial effect of birds, lizards and reptiles in reducing insect pests. By the end of the 19th century the use of parasitoids was recommended as a method of controlling agricultural insect pests in Puerto Rico as well as worldwide.

\section{The 20th Century}

At the turn of the 20th century, several institutions responsible for developments within the discipline were established in Puerto Rico. In 1898, Puerto Rico became a territory of the United States of America, and in 1901 the U. S. Congress authorized the establishment of an Agricultural Experiment Station, known as the Federal Experiment Station. Mr. O.W. Barrett was the station's first entomologist and botanist. His initial contribution was a newsletter in 1902 (Barrett, 1902) dealing with the mole cricket, Scapteriscus vicinus Latr., and the lack of predators or parasitoids in Puerto Rico. He emphasized that only birds exercised control over the mole cricket. In 1906, the first record of Zagrammosoma multilineata Ashm., a parasitoid of the coffee leafminer, Leucoptera coffella Guerin-Ménéville was published (Barrett, 1906).

\section{The 1910s}

In 1910, the sugarcane producers established the Agricultural Experiment Station in Río Piedras, then known as the Insular Agricultural Experiment Station, which was dedicated entirely to the problems of cane production. D.L. Van Dine was its first entomologist. The Australian Mealybug Ladybird, Cryptolaemus montrouzieri Mulsant, was introduced in Puerto Rico in 1912 to control mealybugs in sugarcane (Van Dine, 1912), representing the first introduction of a natural enemy to the Island. Also, Van Dine conducted preliminary studies in the USA on the maggot parasitoid Tiphia sp. In 1913, the Guanica Central hired entomologist E. G. Smyth to work on the problem of white grubs (Phyllophaga spp.) and appointed C.E. Hood as a traveling entomologist to collect white grub parasitoids outside Puerto Rico. Hood died in 
1914, and George N. Wolcott was hired to replace him. Wolcott started his entomological work collecting thousands of Tiphia sp. cocoons in the USA for release in the island's sugarcane fields.

\section{The $1920 \mathrm{~s}$}

From 1920 to 1923, the giant Surinam toad, Bufo marinus Schneider, was introduced from the then British island of Barbados for biological control of sugarcane grubs (Anonymous, 1919; Dexter, 1932; May 1926 and 1930; Sein, 1927). In 1920, the first Puerto Rican entomologist, Francisco Sein, conducted a study of the life cycle of a predator of white grubs, the larvae of cucubano Pyrophorus luminosus Illiger (Sein, 1923). Wolcott in 1924 published the first publication on economic entomology with information on biological control of all pests of economic importance in Puerto Rico. From 1924 to 1927 the Central Aguirre hired the entomologist Dr. Harold Box to introduce parasitoids of the sugarcane borer (Box, 1924, $1928 \mathrm{a}$, b). He also studied the biology of the scoliidae wasps in Puerto Rico, natural parasitoids of Phyllophaga (Box, 1925).

\section{The $1930 \mathrm{~s}$}

The cottony cushion scale, Icerya purchasi Mask, appears in Puerto Rico in 1932-33 and spreads to citrus crops throughout northern Puerto Rico (Wolcott and Sein, 1933). The success of the coccinellid Rodolia cardinalis Mulsant, predator of the cottony cushion scale, was known worldwide, so it was introduced to Puerto Rico from Florida (Anonymous, 1932). In some humid sites, the entomopathogenic fungus Spicaria javanica Bally, which also helped reduce infestations of $I$. purschasi to a minimum, was observed. In 1932 and 1935 another coccinellid, Hyperaspis trilineata Mulsant, among the many species that were introduced to Puerto Rico, was brought from Barbados to control sugarcane mealybugs (Tucker and Wolcott, 1936). In 1936, at the request of Dr. W. R. Thompson (Imperial Institute of Entomology, England), cucubano larvae were sent to the island of Mauritius to help control the white grub, Phyllophaga smithi, Flecha (Bartlett, 1939). Sein introduced the braconid Mirax insularis Muesebeck to Puerto Rico in 1937 from the island of Guadalupe (Sein, 1940) to control the coffee leafminer larva.

\section{The 1940s}

Studies to control the sugarcane borer continued (Dohanian, 1937). Wolcott and Martorell conducted research on the biological control of D. saccharalis eggs by the wasp Trichogramma minutum Riley (Wolcott and Martorell, $1943 \mathrm{a}, \mathrm{b})$. The level of infestation in sugarcane 
remained low for many years due to the beneficial effect of the natural parasitoids, T. minutum, Tetrastichus haitiensis Gahan and the tachinid parasitic fly, Lixophaga diatraeae Townsed.

\section{The $1950 \mathrm{~s}$}

Between 1935 and 1950, the Federal Agricultural Experiment Station introduced from other countries 75 species of parasitoids and predators of various pests of agricultural importance. In the 1950s the station researchers evaluated the introductions and, of the 13-species introduced for biological control of $D$. saccharalis, only one was recovered, Bassus stigmaterus Holloway. The endemic parasitoid L. diatraeae exercised $20-60 \%$ of control. In the case of the fruit fly, Anastrepha spp., they recovered three of the introduced species but found that better control came from the endemic parasitoids (Opius anastrephae Viereck, with $35 \%$ natural control).

\section{The $1980 \mathrm{~s}$}

For more than two decades, biocontrol work remained virtually overshadowed by research on validation and registration of chemical insecticides. In the $1980 \mathrm{~s}$, a resurgence of research on biological control was focused more on faunal surveys of parasitoids (Abreu- Rodríguez, 1982; Armstrong, 1981 and 1987; Ashley, 1986; Bennett and Noyes, 1989; Bennett et al., 1987; Castner and Fowler, 1984; Castro, 1986; Figueroa, 1983; Franqui et al., 1988; Franqui, 1987; Gallardo-Covas, 1988; Medina et al., 1989; Pantoja et al., 1985; Pantoja et al., 1989). In 1988 the citrus blackfly, Aleurocanthus woglumi Ashby, was detected in Puerto Rico and a year later the parasitoids Amitus hesperidum and Encarsia opulenta Silvestri were introduced from Florida (Medina-Gaud et al., 1991). They had reduced populations of the citrus blackfly to such low densities that it no longer was a pest problem in Puerto Rico (Browning, 1992).

\section{The 1990s}

One of the most devastating crop pests of cucurbits in Puerto Rico during the 1990s was the melonworm, Diaphania hyalinata Linnaeus. Farmers were confronted with melonworm populations increasingly resistant to insecticides. During 1991, approximately 293 individuals of the braconid Cardiochiles diaphaniae W. were introduced from Florida and released at the Agricultural Experiment Station of Juana Díaz and on a farm in the town of Guayanilla. Cardiochiles became permanently established and were recovered on the southern coast of Puerto Rico years later; percentages of $34 \%$ were reported, decreasing the ravages of the melonworm (Gallardo et al., 2012). 
Another success in biocontrol was the depredation of a complex of natural enemies (Coccinellidae) on the black citrus aphid (BCA), Toxoptera citricida Kirkaldy, which was detected in Puerto Rico in the early 90s (Michaud, 1996). Michaud (1996) found several species of ladybirds, which were introduced in the years 1930-1940, observing relatively good biological control of BCA in Puerto Rico throughout the summer months of 1996. Between May and August, fewer than 5\% of suitable citrus terminals were infested with BCA in most citrus groves, largely due to the activity of various species of coccinellid, the adults and larvae of which destroyed most BCA colonies in their early stages. The most abundant species were Coelophore inaequalis and Cycloneda sanguinea.

\section{The $21^{\text {st }}$ Century}

Decade 2000

In 1999 the papaya mealybug, Paracoccus marginatus Williams and Granara of Willink, was detected in Puerto Rico (Pantoja, 2007). A classical biological control program was started in a joint effort of the Departments of Agriculture of the United States, Puerto Rico and the Dominican Republic (Ramírez and Saez, 2002). Several encyrtid species were introduced and released in the field with a $97 \%$ control success, liberating papaya growers from the havoc of this pest (Meyerdirk and Kauffman, 2001).

In the 2000 s, two insect pests of citrus and coffee with devastating effects on these crops were found in Puerto Rico: the citrus psyllid, Diaphorina citri Kuway, and the coffee berry borer, Hypothenemus hampei Ferrari. Both have been the subject of many studies for biological control. Also, Tamarixia radiata Waterston (Pluke et al., 2008), which attacked the nymphs of $D$. citri at a 79 to $88 \%$ incidence, coincidentally appeared. The incidence of parasitism at Isabela, Puerto Rico, ranged from 79 to $88 \%$ between January and April. High rates of parasitism in the spring were followed by continuously reduced psyllid populations during the summer. Parasitism rates generally exceeded $50 \%$ and averaged $70 \%$ in Isabela but were more variable and averaged $38.5 \%$ in Corozal and Gurabo, where psyllid populations were lower and more variable.

2010-15

In 2010, the entomogenous fungus Beauveria bassiana (Bals. -Criv.) Vuill. was observed naturally infecting the coffee berry borer (Gallardo et al., 2010). Although low density was reported, the parasitoid Cephalonomia stephanoderis Betrem appeared (Unpublished data). 


\section{CONCLUSION}

Biological control as a viable method to reduce pest populations to acceptable levels is often more difficult to evaluate than control practices that have an immediate response in the mortality of the pest, such as the use of insecticides or microbial pesticides. The lack of such rapid response in mortality left farmers to consider biocontrol a last option in pest control. Most biological control work in Puerto Rico has been focused on recognizing the natural enemy fauna or new records of parasitoids (taxonomy work) with very few forays into other biological control research approaches. At the beginning of the 20th century the classical approach of searching for natural enemies in the place of origin of the pest, collecting and releasing them in the pest problem area, was recognized worldwide as the best approach. Thus, institutional policy for the development of biocontrol programs in Puerto Rico was focused on applied control introducing natural enemies.

During the period covered by this review, 407 research papers on the biological control of insect pests were published. The 1930s was the most prolific decade with the largest number of research papers published on biocontrol of insect pests (Figure 1). This was due to the arrival of several entomologists in Puerto Rico to resolve the main production problems of sugarcane, the white grubs (Phyllophaga spp. and Diaprepes sp.) and the borer (D. saccharalis). In fact, these were the most studied insect pests in Puerto Rico; $38.93 \%$ of research papers published were devoted to them because sugarcane was the main crop in Puerto Rico until the mid 1970s. Sixty percent of research publications were dedicated to the use of parasitoids (Figure 2) in which braconids,

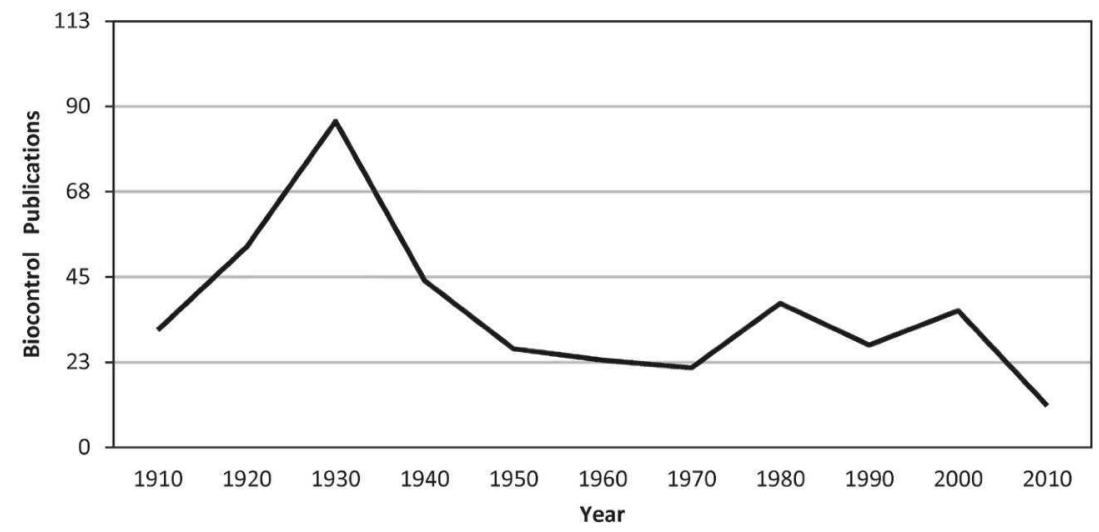

FIGURE 1. Research papers published on biological control of insect pests in Puerto Rico. 


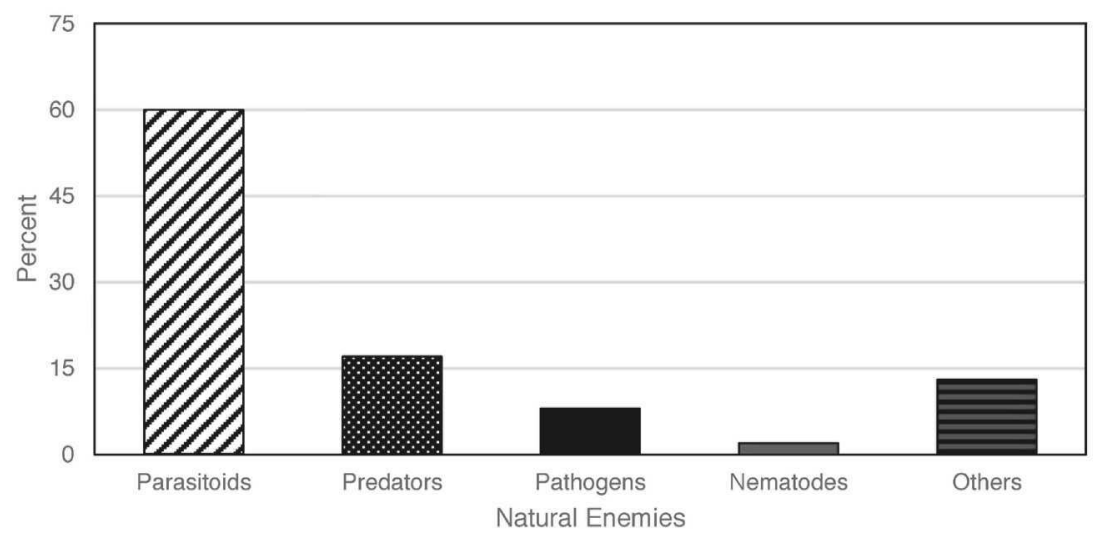

FIgURE 2. Research publications by natural enemy in Puerto Rico.

followed by encyrtids, were the most studied with 18 and $13 \%$ of all published works, respectively (Table 2).

In evaluations of the classical introductions, only $27.27 \%$ showed a degree of complete success while more than $50 \%$ were unsuccessful (Table 1). This information is based on written reports of researchers. However, by its very nature, classical biocontrol is a long-term process and pest populations vary over time. Thus, short-term evaluations are not good enough to determine whether classical biocontrol works. A lack of long-term post-evaluation is evident in the literature.

Finally, after categorizing all the published papers on biological control in Puerto Rico, we found 53\% of the work has been done in taxonomy, $29 \%$ on introduction, $15 \%$ on augmentation and $3 \%$ in conservation. The recognition of endemic natural enemies is essential to evaluate the actual impact of the natural enemies and to determine which is the best approach for a biocontrol program. In conclusion, in Puerto Rico, biological control of insect pests has been considered important for suppressing pest populations. However, its effectiveness must be demonstrated, and the institutions responsible for implementing agriculture policies should make stakeholders and the public aware of the importance and success of biological control.

TABLE 1.-Success of classical biological control in Puerto Rico.

\begin{tabular}{lc}
\hline Degree & Percent \\
\hline Complete & 27.27 \\
Partial & 25.00 \\
Failure & 20.45 \\
Unknown & 27.27 \\
\hline
\end{tabular}


TABLE 2.-Percentage of research publications devoted to parasitoid families of Hymenoptera.

\begin{tabular}{lc}
\hline Family & Percentage \\
\hline Signiphoridae, Ichneumonidae & 1.21 \\
Sphecidae, Aphelinidae, Tiphidae, Pteromalidae & 4.87 \\
Trichogrammatidae, Eulophidae & 10.97 \\
Formicidae, Chalcididae & 12.19 \\
Encyrtidae & 13.41 \\
Braconidae & 18.29 \\
\hline
\end{tabular}

\section{LITERATURE CITED}

Abreu-Rodríguez, E., 1982. Adactylidium sp. (Acarina: Pyemotidae) a new record of a predatory mite of thrips eggs in Puerto Rico. J. Agric. Univ. P.R. 66(4): 310.

Anonymous, 1932. Florida beetle put to test, curbing Puerto Rico citrus pest. The Produce News 1932, front page.

Anonymous, 1919. Skunks and toads. Agric. News, Barbados, BWI. 18 (458): 361.

Armstrong, A. M., 1987. Parasitism of Tetrastichus haitiensis Gahan on egg masses of Diaprepes abbreviatus in Puerto Rico. J. Agric. Univ. P.R. 71(4): 407-409.

Armstrong-Ramírez, A. M., 1981. Distribución de Diaprepes abbreviatus L. (Coleoptera: Curculionidae) y Tetrastichus haitiensis Gahan (Hymenoptera: Eulophidae) en las áreas cañeras del norte y noreste de Puerto Rico. Tesis de Maestría. Univ. de Puerto Rico - Recinto Universitario de Mayagüez.

Ashley, T. R., 1986. Geographical distribution and parasitization levels for parasitoids of the fall armyworm, Spodoptera frugiperda. Fla. Entomol. 69: 516-524.

Barrett, O. W., 1906. Report of the entomologist and botanist. Investigations in entomology and plant pathology. Puerto Rico Agric. Exp. Sta. (Mayagüez), Rept. for 1905, pp 22-23.

Barrett, O. W., 1902. The changa or mole cricket. Puerto Rico Agric. Exp. Sta. (Mayagüez). Bul. 2: 1-19.

Bartlett, K. A., 1939. The results of shipments of the predatory elaterid beetle Pyrophorus luminosus from Puerto Rico to England. Bull. Entomol. Res. 30(2): 209-210.

Bennett, F. D., H. Glenn, M. Yaseen and R. M. Baranowski, 1987. Records of' Trichospilus diatraeae, an Asian parasite (Hymenoptera: Eulophidae) from the Caribbean and Florida. Fla Entomol. 70: 184-18.

Bennett, F. D. and J. S. Noyes, 1989. Three chalcidoid parasites of diaspines and whiteflies occurring in Florida and the Caribbean. Sci. Notes, Fla. Entomol. 72(2): 370-373.

Box, H. E., 1928a. Observations on Lixophaga diatraeae Townsend, a tachinid parasite of Diatraea saccharalis Fabr. in Porto Rico. Bull. Entomol. Res. 19 (1): 1-6.

Box, H. E., 1928b. The introduction of braconid parasite of Diatraea saccharalis Fabr., into certain of the West Indian Islands. Bull. Entomol. Res. 18 (4): 365-370.

Box, H. E., 1925. Porto Rican cane-grubs and their natural enemies, with suggestions for the control of Lamellicorn larvae by means of wasp-parasites (Scoliidae). J. Agric. Univ. P.R. 9(4): 291-356.

Box, H. E., 1924. Report upon a trip to Puerto Rico, April-July 1924 (for private circulation). S. Dawson \& Company Ltd. 22 pp.

Browning, H. W., 1992. Overview of biological control of Homopterous pests in the Caribbean. Fla Entomol. 75(4): 440-445.

Castner, J. L. and H. G. Fowler, 1984. Distribution of mole crickets (Orthoptera: Gryllotalpidae: Scapteriscus) and the mole crickets parasitoid Larra bicolor (Hymenoptera: Sphecidae). Fla. Entomol. 67(3): 481-484.

Castro, S., 1986. Hormigas depredadoras de larvas neonatas de Diaprepes abbreviatus (Coleóptera: Curculionidae). Tesis de Maestría, Universidad de Puerto Rico, Recinto Universitario de Mayagüez. $72 \mathrm{pp}$. 
Dexter, R. R., 1932. The food habits of the introduced toad, Bufo marinus, in the sugarcane section of Puerto Rico. Int. Soc. sugar-cane tech. Fourth Congress. Bull 74: 1-6.

Dohanian, S. M. 1937. The introduction of parasites of the sugarcane borer into Puerto Rico. J. Agric. Univ. P.R. 21(2): 237-241.

Figueroa, E., 1983. Ciclo vital y enemigos naturales de Heliothis zea en maíz. Tesis de Maestría, Universidad de Puerto Rico, Recinto Universitario de Mayagüez. 110 pp.

Franqui, R. A., 1987. Bionomics of Stink Bugs Affecting Rice Fields in Puerto Rico. M.S. Thesis Univ. P.R. Mayagüez Campus, Mayagüez Puerto Rico.

Franqui, R. A., A. Pantoja and S. Medina-Gaud, 1988. Natural enemies of pentatomids affecting rice fields in Puerto Rico. J Agric. Univ. P.R. 72(3): 371-374.

Gallardo, F., O. P. González and H. Pérez, 2012. Presencia de Cardiochiles diaphaniae W. Parasitoide de Dyaphania hyalinata L. en cultivos de calabaza en Puerto Rico: Veinte años después. Memorias Reunión Científica Anual de la Sociedad Puertorriqueña de Ciencias Agrícolas. Nov. 2011. Ponce, PR.

Gallardo-Covas, F., 1988. Faunal survey of the coffee leaf miner, Leucoptera coffeella, parasitoids in Puerto Rico. J. Agric. Univ. P.R. 72(2):255-264.

Gallardo-Covas, F., E. Hernández and J. Pagán, 2010. Presencia natural del hongo Beauveria bassiana (Bals.) Vuill. en la broca del café Hypothenemus hampei (Ferrari) en Puerto Rico. J. Agric. Univ. P.R. 94 (1-2): 195.

Gundlach, J., 1887. Apuntes para la fauna Puerto-Riqueña. VI. Crustáceos. Anales de la Sociedad Española de Historia Natural 15: 115-199.

Ledrú, A. P., 1810. Voyage aux iles de Tenerife, La Trinité, Sainte-Tomas, Sainte-Croix et Porto-Ricco. Exéxuté par ordre du govermenement Francais. Tome premier. Chez ArthusBertand, Libraire, rue Hautefeuille, no. 23 Paris, France.

López-Tuero, F., 1895. La caña de azúcar en Puerto Rico, su cultivo y enfermedad. Puerto Rico tip. Boletín Mercantil. 123 pp.

May, D. W., 1930. Report of the Director. Puerto Rico (Mayagüez) Agric. Exp. Sta. Rept. for 1929 , p. 4, 1 fig.

May, D. W., 1926. Agricultural notes. Puerto Rico (Mayagüez) Agric. Exp. Sta. Ext. Leaflet 2621-2.

Medina-Gaud, S., E. Abreu, F. Gallardo and R. A. Franqui, 1989. Natural enemies of the melonworm, Diaphania hyalinata L. (Lepidoptera: Pyralidae) in Puerto Rico. J. Agric. Univ. P.R. 73(4): 313-320.

Medina-Gaud, S., A. E. Segarra-Carmona y R. A. Franqui, 1991. La mosca negra de los cítricos, Aleurocanthus woglumy Ashby (Homoptera: Aleyrodidae), en Puerto Rico. J. Agric. Univ. P.R. 75(3): 301-305.

Meyerdirk D. E. and W. C. Kauffman, 2001. Status on the development of a biological control program for Paracoccus marginatus Williams, papaya mealybug. Internal USDA, APHIS, PPQ Report.

Michaud, J. P., 1996. Observations on the natural enemies of brown citrus aphid in Puerto Rico. Citrus Ind., Aug. issue.

Pantoja, A., C. M. Smith and J. F. Robinson, 1985. Natural control agents affecting Spodoptera frugiperda (Lepidoptera: Noctuidae) infesting rice in Puerto Rico. Fla. Entomol. 68(3):488-490.

Pantoja, A., R. A. Franqui and S. Medina-Gaud, 1989. Natural enemies and alternate hosts of Marasmia trapezaris (Guenée) affecting rice in Puerto Rico. J. Agric. Univ. P.R. 73(4): 397-398.

Pantoja, A., E. Abreu, J. Peña and W. Robles, 2007. Paracoccus marginatus Williams and Granara de Willink (Homoptera: Pseudococcidae) affecting papaya in Puerto Rico. J. Agric. Univ. P.R. 91(3-4): 223-225.

Pluke, R. W. H., J. A. Qureshi and P. A. Stansly, 2008. Citrus flushing patterns, Diaphorina citri (Hemiptera: Psyllidae) populations and parasitism by Tamarixia radiate (Hymenoptera: Eulophidae) in Puerto Rico. Fla. Entomol. 91(1): 36-42.

Ramírez, A. and L. Sáez, 2002. Papaya mealybug (Paracoccus marginatus) in Puerto Rico. Biological Control Laboratory, Dept. Agriculture of Puerto Rico. Training 
Workshop Papaya Mealybug Biological Control Program. Oct. 23-25, 2002, San Juan, Puerto Rico. 7pp.

Seín, F., 1940. Ann. Rep. P. R. Agric. Exp. Stn. 1938-39. pp.50-52. Washington, D.C.

Sein, F., 1927. El sapo. Rev. Agric. Puerto Rico 19(5): 238.

Sein, F., 1923. El cucubano, Pyrophorus luminosus Illiger. Exp. Agric. Ins. Ciencia 80: 1-8.

Tucker, R. W. E. and G. N. Wolcott, 1936. Parasite introductions: Barbados and Puerto Rico. Fifth Congress, Int. Soc. Sugar Cane Techn. Brisbane, Queensland. Sept. 1935, pp 398-405.

Van Dine, D. L., 1912. Progress report on introduction of beneficial parasites into Porto Rico. Bd. Comm. Agric. P.R. int. rept. pp. 31-47.

Wolcott, G. N., 1924. Entomología Económica Puertorriqueña. Est. Exp. Ins. Puerto Rico Bol. 32. 1-176.

Wolcott, G. N. and L. F. Martorell, 1943a. Control of sugarcane borer in Puerto Rico by laboratory reared parasites. J. Econ. Entomol. 36(3): 486.

Wolcott, G. N. and L. F. Martorell, 1943b. Natural parasitism by Trichogramma minutum of the eggs of the sugarcane north borer, Diatraea saccharalis, in the cane fields of Puerto Rico. J. Agric. Univ. P.R. 27(2): 39-83.

Wolcott, G. N. and F. Sein, Jr. 1933. A year's experience with the cottony cushion scale in Puerto Rico. Puerto Rico Dept. Agric. J. 17: 199-21. 